\title{
Cell Rehabilitation: Molecular and Biochemical Aspects
}

\begin{abstract}
Ahed J Alkhatib*
Department of Legal Medicine, Toxicology and Forensic Medicine, Faculty of

Medicine, Jordan University of Science and Technology, Jordan

*Corresponding Author: Ahed J Alkhatib, Department of Legal Medicine,

Toxicology and Forensic Medicine, Faculty of Medicine, Jordan University of

Science and Technology, Jordan.
\end{abstract}

While diseases in general seem to affect tissues, cells are the main axis of influence. Cell cycle changes have been described to be under the processes of change. In general, cells are deviated from normal function during disease. Some changes are reversible and can be treated within current therapeutic standards. On the other hand, other changes are irreversible and not treatable within therapeutic options. Examples include changes in chronic diseases such as diabetes and cardiovascular diseases. Other examples include cancerous changes. Our previous studies showed that there is a possibility to understand these diseases from different points of view and restoring normal function of cells is within research output. Epigenetic changes have been revealed to play important roles in cases of chronic diseases. We have previously shown some changes in acute myeloid leukemia (AML) to be explained by epigenetics. Our data showed that the expression of WT1 and p53 followed certain patterns that permit the prediction of occurrence and progression of AML.

The idea of cell rehabilitation has emerged from these previous works and needs to be further investigated. At cellular level, there are several factors that influence the cell function and ageing. Among these factors, are the existence of oxidizing agents, heavy metals, and elements from nervous system such as inducible nitric oxide synthase (iNOS).

I think that removing of these barriers could help in restoring cell function and as a result cell rehabilitation.
Received: January 30, 2020

Published: March 01, 2020

(C) All rights are reserved by Ahed J Alkhatib.

\section{Assets from publication with us}

- Prompt Acknowledgement after receiving the article

- Thorough Double blinded peer review

- Rapid Publication

- Issue of Publication Certificate

- High visibility of your Published work

Website: www.actascientific.com/

Submit Article: www.actascientific.com/submission.php

Email us: editor@actascientific.com

Contact us: +919182824667

Citation: Ahed J Alkhatib. “Cell Rehabilitation: Molecular and Biochemical Aspects". Acta Scientific Pharmaceutical Sciences 4.4 (2020): 01. 